\title{
Atypical or Non-Standard Work: A Challenge to Workers' Protection in South Africa
}

\author{
Mashele Rapatsa \\ PhD student, University of Groningen, Globalisation Studies and Humanitarian Action, Netherlands, \\ Faculty of Management and Law, Department of Mercantile and Labour Law, \\ University of Limpopo (Turfloop Campus), South Africa \\ m.j.rapatsa@rug.nl
}

\section{Doi:10.5901/mjss.2014.v5n27p1067}

\begin{abstract}
This article discusses the problem of atypical or non-standard work in the light of persistently spiraling challenges that very much threaten the realization of international decent work agenda. The nature and extent of atypical employment has been a critical factor because of its dimension on diminishing the realization of human rights in the workplace. The resultant thereto is burgeoning precarious work, which deprives workers access to their fundamental social necessities associated with decent work. It is revealed that indubitably, atypical work is associated with declining living standards, persistent poverty, societal socio-economic inequalities, diminishing job security and lack of social protection. Thus, it is considered a human rights issue which can best be addressed using the law in the Constitution, 1996 and fundamental international instruments. It is asserted that essential labour legislation should be reformulated to enable it to be responsive in restoring and sustaining its purpose of protecting workers labour rights, and safeguarding their social security in the modern world of work. This is essential for labour peace and social justice, because labour law ought to resonate with the transformative ideals of the Constitution.
\end{abstract}

Keywords: informalization, precarious worker, worker exploitation, social security, transformation

\section{Introduction}

Work is an essential everyday phenomenon that influences the society's socio-economic circumstances and direction. Furthermore, work significantly determines individuals' successes, survival and the extent to which a country's development thrives. Without work, social order experiences major turbulences that impede stable social orientations in the society. It is through work, that people are able to establish how the society changes, attempts to shape it and what problems must be addressed (Houngbo, 2014; Kalleberg, 2009). Thus, work provides all people with an opportunity to realize their full potential and contribute positively to broader humanitarian needs in communities. Therefore, it is important to study the dimensions of atypical or non-standard forms of work to workers labour rights, their social protection and society's developmental goals.

It has been observed that the nature of workforce has changed dramatically over the past decades (Benjamin, 2005; Fredman, 1997). This has largely resulted in the majority of workers rendered vulnerable in precarious situations in as far as both the labour and social security protective legislations are concerned. These changes in the workforce have been given added impetus by the notable global economic recession, the overwhelming levels of soaring unemployment, global market competitions, the introduction of new global technology (Mills, 2004) and privatization amongst others. On that premise, Clive Thompson has emphasized that work has changed and is continuously changing for both better and worse (Thompson, 2003). This assertion is a stern admonition that the recasting and reshaping of labour law has become a very indispensable phenomenon. This is necessary to give effect to the aspirations of South Africa's notion of transformative constitutionalism and the objectives of the Labour Relations Act 66 of 1995 at large. Conspicuously, all these changes call upon labour law to be responsive in restoring and sustaining its purpose of protecting workers against labour rights and safeguarding their social security. It is only through effective regulation of work that the working-class can realize their social and economic fundamentals, which indubitably depends on ending complex realities created by the notion of informal employment. Thus, the continued tripartization of work impedes the effectiveness with regards to the role which labour law should play in governing labour relations.

Thus, the subject of this article is to reflect on the difficulties and sufferings faced by the many precarious workers resultant to common trends of engagement in the contemporary world of work. Notably, this includes informalization, casualization and externalization and other tripartite forms of doing work. All these happens in the name of 'flexicurity' or 'flexibility' (Caldbick et al, 2014; van Eck, 2014), which is of course only a costs cutting contrivance by employers, 
ironically accompanied by extreme components of miserable labor and economic exploitation (Botes, 2012; Pons-Vignon and Anseeuw, 2008). The article also reveals the exponential increase in the intensity of atypical or disguised forms of employment relationships (i.e. inclusive of; temporary, part-time, outsourced and domestic workers) in the modern labour relations. It begins by providing a theoretical framework on the subject and the meaning of atypical employment. Challenges and effects of being a precarious worker are also considered. The article is written in consideration of South Africa's agenda of transformative constitutionalism which, it is asserted that extends beyond just constitutional law, and rather also covers broader areas of societal orientation including labour relations. Notions such as atypical or nonstandard or precarious workers will be used interchangeably to denote workers that do work mostly through tripartite arrangements and the likes.

\section{Methodology}

This article adopts a qualitative method of research. It utilizes descriptive and exploratory methods. Whereas it describes the nature and extent of the problem of atypical work, it also attempts to explore workable approaches towards ending workers exploitation. It is focused at inventing workable mechanisms that can help ease tension in the troubled area of labour law. The aspects of analysis in this article are focused on studying the purpose of labour law and determine whether such is still being achieved or progressively achievable in the midst of the constant circumstances of informalised work. The article adopted content analysis approach relying on data from written texts. It employs four concepts in studying this phenomenon, namely; labour relations, transformation, precarious work(er) and social security. Both primary and secondary sources were relied upon as source material.

\section{Theoretical Framework}

It should be noted that atypical or non-standard employment presents itself as a multifaceted phenomenon that emerged largely as a consequent of subterfuges by employers to reduce their obligations towards employees. These obligations include ensuring progressive social protection in particular and an unlimited access to a wide range of labor protective ambits in general. Subsequently, informalized work became a predominant phenomenon in labour relations (Benjamin, 2008), effectively rendering employment to become what it is not used to be (Theron, 2003). That the continued expansion of informal work is undesirable for workers protection is definitely indisputable. According to Paul Benjamin, this informalization when described, is a process by which employment is increasingly unregulated and workers are least protected or not protected at all, by labour law (Benjamin, 2008). It covers both workers who are nominally covered by labour law but are not able to enforce their rights and those who are not employees as their legal status is that of being independent contractor(s) (Kalula et al, 2008).

It has been through such processes as this that the worldwide prevalence in the nature and extent of precarious worker has increased so significantly in recent years (Houngbo, 2014; Barchiesi, 2010). Regrettably, it has been observed that workers continue to loose enjoyment of labour protection (Benjamin, 2005), with South Africa being no exception, and is supposedly amongst the countries where these phenomena remain pervasive (Cohen and Moodley, 2012). Indeed, the changes brought by these modern trends of work have created varying forms of triangular employment relations that pose a major threat to workers' protection in the country and across the Southern African Development Community (SADC) region (Kalula, et al, 2008). This challenge is most experienced in the most volatile area of the labour market, the informal sector of the economy. Sadly, it has been evinced that the majority of the economically active population in the SADC region work in the informal sector (Fenwick \& Kalula, 2004). Thus, those working in the formal sector of the labour market constitute a minimal percentage which means a standard employment arrangement is steadily melting away. Thompson argues that this affects both emerging and advanced economies (Thompson, 2003). Under such circumstances, the workforce gets divided between those (few) working as permanent employees, and those working on a non-standard or a more precarious basis. For instance, this is with reference to workers procured through labour broking, known temporary employment services (TES's) and other notable forms of labour contracting, through known employment agencies. Ironically formal employment relationships are the focus of labour law in the industrialized world (Kalula, 2008). Thus, the working populace in the informal sector do not benefit from labour law, hence they are referred to as 'precarious workers'. Stuck under least or unregulated working environments, they are a burgeoning and desperate category of workers (Theron, 2003). Then, a precarious worker is produced by the spiraling trends of informalized work. Thus, the context and conceptualization of the notion of a 'precarious worker' is worth considered. According to Kamla Naidoo, being a precarious worker has indeed become one of enormous global challenges undermining the gains of the working class (hard earned democracies in the advancement of social justice) and eroding 
trade union organization (Naidoo, 2010).

It has been argued that precarious work thrives owing to practices that have been designed to maximize employers' profits and flexibility, the effects of which have been to shift risks onto powerless, docile and vulnerable workers. During 2010, the International Metalworkers Federation (IMF) and the Food, Agricultural, Hotel, and Restaurant Workers International (IUF), submitted reports to John Ruggie, the United Nations Speech Representative for Business and Human Rights, alerting him of the intensity of this problematic trend in human rights terms. They both have emphasized that precarious work is systematically undermining human rights of workers. The labour law developments have also suggested that there prevails a dire need to consider establishing probabilities of reshaping and extending labour laws' scope of coverage to include those in desperate need of labour protective legislation. This has been resultant to the exponential increase in the levels of atypical employment. Being a 'precarious worker' entails that a person is in an employment relationship, theoretically protected by certain basic labour rights that applies to all employees, but under arrangements which makes it difficult or almost impossible to access labour legislation, exercise and enforce the labour rights bestowed by such legislation.

Apart from being deprived of unionization rights, precarious workers also suffer major exclusions with regards to benefits fundamentally proffered by social security legislation (Olivier \& Kalula, 2003). Lack of access to adequate social security is amongst the notable critical aspects associated with atypical employment. This is with reference to the growing area of more or less new types of employment, including jobs which are not permanent and/or not full-time. For instance, jobs done on a part-time and fixed-term work basis, temporary-agency work, working from home, tele-work, 'on call' work, seasonal work, student jobs, subcontracted work and the 'pseudo-self-employment' of workers who are in practice bound to and dependent on a single employer (Nyenti, 2007). These categories of workers fall short of meeting the criterion that enables them to have an assured social security. Most importantly, precarious worker would also encompass those that are expressly excluded by virtue of the labour legislation. This is in accordance with the context of defining an 'employee' in terms of the Section 213 and Section 200A of the Labour Relations Act 66 of 1995; Section 83A of Basic Conditions of Employment Act 75 of 1997; Section 1 of Employment Equity Act 55 of 1998 and Section 1 of Skills Development Act 97 of 1991. This is necessarily because defining an employee is a major entry point to qualify for labour protective framework (Rapatsa, 2014).

With regards to aspects of unionization and collective bargaining, workers secured through tripartite engagements suffer exclusions as well. This implies that terms and conditions of their employment are unilaterally pre-determined by their so-called employers and imposed unto them. As a result, precarious workers have no latitude or right to challenge any provision in those terms of their employment because there is very little proffered for their protection. Moreover, work may be terminated instantly without due processes being adhered to, this to the detriment of social justice.

On aspects of exclusions in terms of social insurance, precarious workers are first subjected to poor working conditions, low wages, less job security and in certain instances, the long term effect of income insecurity. They do not enjoy benefits as enjoyed largely by workers in standard employment (for instance, medical aid, annual leave, paid maternity leave, pension, study or training benefits and so forth).

Precarious work is also understood in the context of being the driving instrument behind the declining living standards, discrimination, the feminization or poverty and other aspects (Rapatsa and Matloga, 2014). This is particularly prevalent especially amongst populations that live in under-developed and developing countries (Beneria, 2001). It is referred to as employment that is of low quality and that encompasses a range of factors that put workers at risk of injury, illness and/or poverty. It is without a doubt that workers in these genuses of employment arrangements are subjected to a dire sui generis exploitation, necessarily because the usual circumstances of their employment render the enforcement of their rights extremely problematic (Fourie, 2008).

\section{Transformative Agenda and Labour Legislative Framework}

Uneasiness over conditions and (social) security of workers in employment environments is not entirely a new phenomenon. It has always been amongst the leading factors influencing labour law developments in South Africa. During the late 1970s, the Wiehahn Commission was appointed to investigate the status of labour laws, in the midst of popular knowledge with regards to their exploitive and discriminatory orientation on labour rights. The Commission recommended extensive reforms including on organizational rights, right to fair labour practices (Landman, 2004), social protection and other aspects. Then, in the 1990s, transition into democratic dispensation led to inclusion of labour rights in the Constitution to reflect on a broader transformative philosophy.

Thus, South Africa's background in labour relations cannot be complete without highlighting the landmark constitutional changes that gave effect to recognition of labour rights, its protection and enforcement thereto. This 
eventually culminated in a firm foundation for any discussions regarding the primary purpose(s) that labour law ought to play in a continuously dynamic and evolutionary field of work. This is considerate of the ongoing global agenda geared towards achieving decent work for everyone in employment. However, whether labour law is still capable of achieving its purpose in the midst of notable contemporary challenges such as the increased levels of atypical employment is a matter for constant debate. Notably, the primary purpose of labour law resonates with South Africa's transformative constitutionalism agenda. According to Kahn-Freund, labour law is traditionally concerned with social power, and it is therefore destined to serve as 'a countervailing force' to address the skewed and ever skewing power relations that exist between employers and employees (Davies \& Freedland, 1983). Hence, labour law functions as an intervening instrument in markets to achieve justice which otherwise will not be realizable were labour markets to remain unregulated (Hyde, 2006; Kalula, 2004; Hepple, 1995). In the context of South Africa, this regards the present constitutional and labour legislative framework that has been put in place to reflect the corresponding values of the Constitution, especially in labour relations.

The primary point of departure is section 23 of the Constitution which provides an overarching framework for protection of workers' labour rights. It guarantees every worker the protection against unfair labour practices. Consequently, when subjected to literal interpretation, section 23 requires that every worker should be protected against exploitation and other workplace malpractices. Arguably, this should encompass all workers regardless of existing subterfuges by employers attempting to hide realities in employment relationships (White $v$ Pan Palladium SA (PTY) (2006) 27 ILJ 2721 (LC): p2727J - 2728A; Denel (Pty) Ltd v Gerber (2005) 26 ILJ 1256 (LAC): p1296G). The Labour Relations Act 66 of 1995 and Basic Conditions of Employment Act 75 of 1997 were promulgated particularly to give effect to the notable constitutionally entrenched labour rights. This has been informed by the need to augment the transformative ideals of realizing labour peace, social justice and social security amongst others. However, the primary labour legislation (LRA) is not without critiques. This is necessarily because it is foundational in determining who reaches labour protective ambits, yet it limits access only to those who are recognized as employees, leaving the majority of workers outside standard employment with little or without protection at all. Section 213 of the LRA thus defines an employee as follows;

a) Any person, excluding an independent contractor, who works for another person or the state and who receives, or is entitled to receive, any remuneration; and

b) Any other person who in any manner assists in carrying on or conducting the business of an employer.

Interestingly, a somewhat incompatible position between the Constitution and the LRA is uncovered. This is discernible from the fact that the Constitution seeks to protect every worker, whereas the LRA invented its own exclusions. To date, this remains questionable and of course it is a subject of robust discussions amongst legislatures, trade union organizations and business. In terms of section 2 of the Constitution, any law or conduct inconsistent with it should be declared invalid. In this case, I invoke to say 'unconstitutional'. Accordingly, any maneuver which attempts to exclude other workers from benefiting in terms of this constitutional protection is unconstitutional. Having said this, the LRA seem to have compounded the situation further with widespread practices of non-standard employment unbroken. Section 198 of the LRA authorizes the use of Temporary Employment Services (TES). This arguably gave rise to labour broking and other forms of procuring persons to do work for third parties.

Evidently, the problem of precarious worker is the result of the very legislation which was ironically promulgated to safeguard the interests of workers. Notwithstanding this challenge, courts have been prepared to intervene by reiterating the supremacy of the Constitution. That is, courts have opted to interpret the Constitution in a manner that fulfills the spirit and purport of protecting the vulnerable workers in the society. Thus, courts ought to disregard invented labels, and rather focus on establishing the substance in determining the nature of the relations between parties to work (SABC $v$ McKenzie (1999) 1 BLLR (LAC): p10). This was also reflected in various jurisprudence where courts have opted to give regard to the pervasive exploitative effects of informalized work on workers and afford worker protection (Kylie $v$ CCMA \& others 2010 (4) SA 383 (LAC); Discovery Health Ltd v CCMA (2008) 29 ILJ 1480 (LC); Denel (Pty) Ltd v Gerber (2005) 26 ILJ 1256 (LAC)).

\section{The Decent Work Agenda and Challenges}

Atypical work must categorically be replaced by decent work. This is the only workable way to realize a socially just global economy premised on foundations of respecting and protecting labour rights. This decent work agenda is an integrated international project led by International Labour Organization (ILO) in cooperation with national governments. It is fundamental in transforming the persistent predicaments faced largely by atypical workers. Aspects that may be essential in dealing with questions concerning what constitute decent work can be enumerated to include the following; Firstly, 
work must recognize and protect human rights in the workplace. Secondly, work is decent if it offers satisfactory wages, productivity and benefits. Thirdly, work should have security and be accompanied by worthy social security measures. Fourthly, there must be sound and stable workplace relations, which facilitate a greater social integration in society. These and other indicators may assist in determining whether work is decent or not. Without decent work, poverty and inequalities will remain pervasive. This shall in turn make Millennium Developments Goals unrealizable or at least difficult to achieve. Thus, the decent work agenda bears all the tasks of altering exploitative arrangements in labour relations. The primary goal being, to promote better human welfare across all nations (Cohen \& Moodley, 2012). This entails that once decent work is achieved, atypical work shall effectively come to an end.

I now turn to findings with regards to where to actually turn the tides. Notwithstanding all the ostensible efforts, there remain critical challenges that are found standing on the way of achieving decent work. This varies from social, economic and legal perspectives, all of which are interconnected critical determinants of decent work. First, the constant global competition in labour and social protection. According to Houngbo (2014), this occurs because demand for labour is increasingly international while supply is regulated at the national level. This result in divergent in terms of regulation of work, and eventual simplicity of market exploitations by unscrupulous employers who prey on docile workers. These divergences hinder the effectiveness of labour standards as if it were left on upon national legislators to decide. Second, the everlasting tension between market competitions and respect for human rights. This concerns instances where market competitors haphazardly prioritize making profit at the expense of respect for human rights, even if it means sacrificing equity, human dignity and security of workers. Subsequently, market forces drive competition to the detriment of values of social justice in the workplace. This is particularly rife in developing economies where egoism drives passion for wealth than sustainable social cohesion. Third, lethargic implementation and application of ILO standards at the national level. While ILO standards may have good appeal, their implementation is still contingent on extra efforts put at the national level. Therefore, if the national governments do not take necessary measures, then decent work agenda will remain an exercise for impression purposes. Fourth, the problem of lack of political will. This happens when politics supersedes every sphere in the society. It is very rampant when politicians, who happen to be legislators and policy makers, are similarly involved in business. Houngbo asserts that very often than not, legislators and policy makers forget the importance of decent work in their engagements seeking to shape and manage global economy. It is reasonably discernible that this happens owing to conflict of interests. Hence, business biased decisions play a significant role in perpetuating exploitative labour practices. This result in ILO instruments being ineffective in terms of producing the desired result nationally.

\section{Conclusion}

It has been revealed that major problems associated with atypical employment substantiate that the labour rights and other rights embodied in the Constitution cannot meaningfully filter through this area. This then leaves workers without (adequate) legal protection, hence reduced or non-existent social security. They are therefore rendered vulnerable and become subjects of exploitation. Subsequently, poverty and inequalities spirals. According to Kalula (2004), South Africa's labour law developments require a solid break from a cycle of 'borrowing and bending'. This entails that the present realities in employment relations can best be addressed using a reformulated labour law which finds its expression through original foundation according to circumstances of its jurisdiction. It is only through committing to tackle issues of inequalities and under-development that labour law would be capable of making the desired impact in altering workers' plight. The only instrumental mechanism to achieve this is by appreciating the significant role played by transformative ideals of the Constitution. Thus, labour law should unreservedly be streamlined according to significant human rights approaches employed by the Constitution, which was primarily informed by the material conditions in the country.

\section{References}

Barchiesi, F. (2010). Informality and Casualization as Challenges to South Africa's Industrial Unionism: Manufacturing Workers in the East Rand/Ekurhuleni Region in the 1990s. African Studies Quarterly, 11:2, 68-85.

Beneria, L. (2001). Changing Employment Patterns and the Informalization of Jobs: General Trends and Gender Dimensions. International Labour Office, Geneva, Switzerland.

Benjamin, P. (2013). Law and practice of private employment agency in South Africa. International Labour Office, Geneva, Sectoral Activities Department., No. 292, 1-32.

Benjamin, P. (2008). Informal Work and Labour Rights in South Africa. Development Policy Research Unit, School of Economics, UCT, 1-27. 
Benjamin, P. (2005). A Review of Labour Markets in South Africa: Labour Market Regulation - International and South African Perspectives. Human Sciences Research Council, 1-63.

Botes, A. (2013). The History of Labour Hire in Namibia: A Lesson for South Africa. Potchefstroom Electronic Journal, 16:1, 506-536.

Caldbick, S., Labonte, R., Mohindra K.S., \& Ruckert, A. (2014). Globalization and the rise of precarious employment: the new frontier doe workplace health promotion. Global Health Promotion, SagePublications, 21:2, 23-31.

Cohen, T. \& Moodley, L. (2012). Achieving "Decent Work" in South Africa? Potchefstroom Electronic Journal, 15:2, 320-344.

Davies, P. \& Freedland, M. (1983). Khn-Freund's Labour and the Law. (3rd ed.). London: Stevens \& Sons Ltd.

Fenwick, C. \& Kalula, E. (2004). Law and Labour Market Regulation in East Asia and Southern Africa: Comparative Perspectives' Occasional Paper 2,. Institute of Development and Labour Law, UCT.

Fourie, E.S., (2008). Non-standard Workers: The South African Context, International Law and Regulation by the European Union. Potchefstroom Electronic Journal, 4, 110-152.

Fredman, S. (1997). Labour Law in flux: The Changing Composition of the Workforce. Industrial Law Journal, 26, 337- at p337-351.

Hepple, B. (1995). The Future of Labour Law. Industrial Law Journal, 24, 303-322.

Houngbo, G. (2014). Key challenges for labour rights protection on a global scale. Conference on Fostering Labour Rights in the Global Economy 20-21 February 2014, Leuven Centre for Global Governance Studies.

Hyde, A. (2006). What is Labour Law? In Davidov, G. \& Langille, B. (eds.). Boundaries and Frontiers of Labour Law, (pp37-61). Oxford: Hart Publishing.

Kalleberg, A.L. (2009). Precarious Work, Insecure Workers: Employment Relations in Transition. American Sociological Review, 74, 122.

Kalula, E., Ordor, A.O. \& Fenwick, C. (2008). Labour Law Reforms that Support Decent Work Agenda of Southern Africa. ILO SubRegional Office for Southern Africa, Harare. Issue Paper No. 28.

Kalula, E. (2008). The Decent Work Agenda: An African Perspective on research needs and priorities. In Rodgers, G \& Kuptscha, C. Pursuing decent work goals: Priorities for research, ILO (International Institute for Labour Studies).

Kalula, E. (2004). Beyond Borrowing and Bending: Labour Market Regulation and the Future of Labour Law in Southern Africa. In Barnard, C., Deakin, S. \& Morris, G. (eds.). The Future of Labour Law. (pp275-289). Oxford: Hart Publishers.

Landman, A.A. (2004). Fair Labour Practices - The Wiehahn Legacy. Industrial Law Journal, 25, 805-812.

Mills, S.W. (2004). The Situation of the Elusive Independent Contractor and Other Forms of Atypical Employment in South Africa: Balancing Equity and Flexibility. Industrial Law Journal, 1203-1235.

Naidoo, Kamla, (2010), Understanding Precarious Work in Africa. [Online] Available: http://www.imfmetal.org/index.cfm?c=20470 OR http://www.industriall-union.org/archive/imf/understanding-precarious-work-in-africa (August 25, 2014).

Nyenti, M.A.T. (2007). Labour Flexibility and the Protection of Non-standard workers in South Africa. 5th International Research Conference on Social Security, Warsaw, Poland, 5-7 March.

Olivier, M. \& Kalula, E. (2003). Scope of coverage. In Olivier, M.P. et al, Social Security: A Legal Analysis (pp. 131-137). Durban, Butterworths: LexisNexis.

Pons-Vignon, N. \& Anseeuw, W. (2008). Great Expectations: Working Conditions since the End of Apartheid. Development Policy Research Unit, School of Economics, UCT, 1-23.

Rapatsa, M. (2014). Contract of Employment, Statutory Provisions and Collective Bargaining in Protecting Workers' Labour Rights. Journal of Business Management and Social Sciences Research, 3:8, 5-14.

Rapatsa, M.J. \& Matloga, N.S. (2014). Who Is (Should) Be Covered By Labour Law? Lessons From Kylie v CCMA. Journal of Business Management and Social Sciences Research, 3:5, 105-113.

Theron, T. (2003). Employment Is Not What It Used To Be. Industrial Law Journal, 24, 1247-1282.

Thompson, C. (2003). The Changing Nature of Employment. Industrial Law Journal, 24, 1793-1815.

Van Eck, S. (2014). Revisiting Agency Work in Namibia and South Africa: Any Lessons from the Decent Work Agenda and Flexibility Approach? International Journal of Comparative Labour Law, 49-66. 